\title{
The relationships between obstructive sleep apnea and psychiatric disorders: a narrative review
}

\author{
Związki między obturacyjnym bezdechem sennym a zaburzeniami psychicznymi: \\ przegląd narracyjny \\ Kaja Hanna Karakuła ${ }^{1}$ ABDEF https://orcid.org/0000-0003-1493-8502, \\ Aleksander Ryczkowski ${ }^{2}$ ABDEF, https://orcid.org/0000-0003-2917-0030, \\ Elżbieta Sitarz ${ }^{3}$ ABDEF, https://orcid.org/0000-0001-7503-1838 \\ Jacek Januszewski4 ${ }^{4}$ BDF, https://orcid.org//0000-0003-1023-4081, \\ Dariusz Juchnowicz ${ }^{5}$ ABDEF, https://orcid.org/0000-0003-2027-5469
}

${ }^{1}$ Student Research Group at the I Department of Psychiatry, Psychotherapy and Early Intervention, Medical University of Lublin, Poland

${ }^{2}$ Department of Family Medicine, Medical University of Lublin, Poland

${ }^{3}$ I Department of Psychiatry, Psychotherapy, and Early Intervention, Medical University of Lublin, Poland ${ }^{4}$ Student Research Group at the Department of Forensic Medicine, Medical University of Lublin, Poland ${ }^{5}$ Department of Psychiatric Nursing, Medical University of Lublin, Poland

\begin{abstract}
Introduction: Obstructive sleep apnea (OSA) is the most common sleep-related breathing disorder. Its prevalence tends to increase worldwide. Untreated sleep apnea is associated with a higher risk of metabolic diseases, cardiovascular diseases, stroke, road accidents, and death, but also it is suggested that it increases the risk of mental disorders.

Method: The literature review was based on a search of articles on Medline, Pubmed, and Google Scholar from 2003 to 2021 using the keywords: obstructive sleep apnea; mental disorders; cognitive functions; affective disorders; depression; bipolar disorder; schizophrenia; psychotic disorders. The analysis included original studies, meta-analysis, and review articles.

Discussion: The result obtained from researches published so far does not allow for drawing unequivocal conclusions. There is a lot of bias present in study protocols and inclusion/exclusion criteria. Nonetheless, it seems that some disorders have a better proven correlation with OSA. Cognitive impairment, depression, and anxiety disorders are linked to OSA not only in terms of the overlapping of symptoms but also of a causal relationship. Psychotic disorders and bipolar disorders connections with OSA are confirmed, but they are not yet well understood. All correlations are found to be possibly bidirectional.

Conclusion:

1. Multiple lines of evidence increasingly point towards a bidirectional connection between OSA and mental disorders, and the cause and effect relationship between these two groups of disorders requires further research.

2. Due to reports of an increased risk of OSA with antipsychotic drugs, caution should be exercised when initiating therapy with this type of drug in patients with known risk factors for it.

3. Screening for OSA in psychiatric patients should be introduced as OSA can increase cognitive impairment, affective, and psychotic symptoms.
\end{abstract}

Keywords: Obstructive sleep apnea, OSA, psychiatric disorders

\section{Streszczenie}

Wstęp: Obturacyjny bezdech senny (OBS) jest najczęstszym zaburzeniem oddychania związanym ze snem. Częstość jego występowania na całym świecie rośnie. Nieleczony OBS wiąże się z wyższym ryzykiem zaburzeń metabolicznych, chorób układu krążenia, udaru mózgu, wypadków drogowych i śmierci, ale także naukowcy sugerują, że zwiększa ryzyko zaburzeń 
psychicznych.

Metoda: Dokonano przeglądu dostępnego piśmiennictwa wyszukanego w Medline, Pubmed i Google Scholar, używając słów kluczowych: obturacyjny bezdech senny; zaburzenia psychiczne; funkcje poznawcze; zaburzenia afektywne; depresja; zaburzenie afektywne dwubiegunowe; schizofrenia, zaburzenia psychotyczne oraz deskryptorów czasowych: lata $2003-2021$. Analiza obejmowała badania oryginalne, metaanalizę i artykuły przeglądowe.

Dyskusja: Wyniki uzyskane z dotychczas opublikowanych badań nie pozwalają na wyciągnięcie jednoznacznych wniosków. Protokoły badań i kryteria włączenia/wyłączenia znacznie różnią się od siebie. Niemniej jednak wydaje się, że związek niektórych zaburzeń psychicznych z OBS jest dobrze udowdniony. Zaburzenia poznawcze, depresja i zaburzenia lękowe są powiązane z OBS nie tylko pod względem nakładania się objawów, ale także można doszukać się związku przyczynoskutkowego. Potwierdzono powiązania zaburzeń psychotycznych i zaburzeń afektywnych dwubiegunowych z OBS, ale nie jest on jeszcze dobrze poznany. Stwierdzono, że wszystkie obserwowane korelacje są prawdopodobnie dwukierunkowe.

Wnioski:

1. Wiele dowodów wskazuje na dwukierunkowy związek między OBS a zaburzeniami psychicznymi, a związek przyczynowo -skutkowy między tymi dwiema grupami zaburzeń wymaga dalszych badań.

2. Ze względu na doniesienia o zwiększonym ryzyku OBS po zastosowaniu leków przeciwpsychotycznych należy zachować ostrożność rozpoczynając terapię tą grupą leków u pacjentów ze znanymi czynnikami ryzyka OBS.

3. Należy rozważyć wprowadzenie badań przesiewowych w kierunku OBS u pacjentów psychiatrycznych, ponieważ OBS może on nasilać zaburzenia poznawcze, objawy afektywne i psychotyczne.

Słowa kluczowe: Obturacyjny bezdech senny, OBS, zaburzenia psychiczne

\section{Introduction}

Obstructive sleep apnea (OSA) is the most common sleep-related breathing disorder. It is a chronic disease characterized by repeated episodes of apnea or hypoventilation caused by the collapse of the upper respiratory tract [1]. The apnea-hypopnea index (AHI) or the respiratory disturbance index (RDI) are useful in diagnosing and assessing the severity of the disorder [2]. Based on AHI, which is defined as by the number of apnea or hypoventilation episodes per hour, we can divide OSA into none or minimal (AHI of 0-4), mild (AHI of 5-14), moderate (AHI of 15-29), severe disorder ( $\mathrm{AHI} \geq 30$ ). The $\mathrm{RDI}$ is also sometimes used and includes not only the AHI index but also more subtle respiratory abnormalities [3].

Symptoms of OSA include, among others, increased daytime sleepiness, morning fatigue, headaches, night urination, night sweats, mood disorders, or libido disorders [4]. OSA causes recurrent nocturnal asphyxia, sleep fragmentation, large fluctuations in blood pressure, and increased activity of the sympathetic nervous system [5]. The risk factors are: obesity, male gender, BMI> 25, African Americans ethnicity, older age, genetics, nasal obstruction, hypothyroidism, acromegaly, alcohol, and tobacco intake [6].

The epidemiology of this disease tends to increase worldwide [7,8]. Young et al. (2002) estimated the incidence of OSA at $5 \%$ in the general population, of which $20 \%$ had a minimally symptomatic or asymptomatic disease [9]. A 2004 study in Israel showed that sleep apnea was diagnosed in $24 \%$ of men and $9 \%$ of women, of which $2-4 \%$ of all participants required medical intervention
[10]. According to Heinzer et al., in 2013, in the general population of Switzerland, OSA occurred in $49.7 \%$ of men and $23.4 \%$ of women [5].

In the United States, over $80 \%$ of mild and moderate OSA cases remain undiagnosed [11]. Untreated disorders of this type are associated with an increased risk of metabolic diseases [12], cardiovascular diseases, stroke, workplace mistakes, road accidents, and death [13]. Researches also suggest that people suffering from sleep apnea have an increased risk of mental disorders [14, 15, 16]. The most common ones include: cognitive disorders $[17,18]$, affective disorders $[16,18,19]$, anxiety disorders [18], post-traumatic stress disorder [20], and psychosis [19].

Patients with apnea often report reduced quality of life, mostly due to cognitive and psychological impairment [21]. According to Karkoulias et al., they have statistically significant poorer mental health [22]. Rezaeitalab et al. (2014) showed in their study that anxiety in all people suffering from obstructive sleep apnea is higher than in the general population. Symptoms of depression and anxiety are more commonly found in people with OSA, than a typical manifestation of this disease [23]. Kaufmann et al. (2017) noted that people suffering from OSA were 3.11 times more likely to be depressed, 2.75 times more likely to have suicidal thoughts, 3.68 times more likely to experience anxiety, and 2.88 times more likely to experience severe mental stress than healthy people [24].

There are pieces of evidence suggesting a link between OSA and mental disorders. From the 1970s researchers recognized the presence of psychological 
symptoms in patients with OSA, but until today it is unknown to what extent they interact [25]. It is understood that the connections between OSA and mental disorders are bidirectional: in OSA mental disorders are more common, and mental disorders are also more commonly accompanied by OSA [26].

Taking into account the healthy, social, and economic consequences of untreated OSA, especially in the population of people with mental disorders, it is extremely important to present the current state of knowledge in the field of relationships in terms of these two disorders.

This narrative review aims to describe the relationship between obstructive sleep apnea and selected mental disorders.

\section{Method}

The literature review was based on a search of articles on Medline, Pubmed, and Google Scholar from 2003 to 2021 using the keywords: obstructive sleep apnea; mental disorders; cognitive functions; affective disorders; depression; bipolar disorder; schizophrenia; psychotic disorders. The analysis included original studies, metaanalysis, and review articles.

\section{Results}

\section{OSA and cognitive impairment}

Studies have observed that OSA is associated with a high risk of cognitive impairment (CI) [27, 28, 29, 30]. Beaudin et al. in 2021 conducted a clinical cohort study in which they noted that CI was present in $47.9 \%$ of OSA patients and it increased with the severity of the symptoms [31]. In another systematic review, the prevalence of OSA in patients with mild cognitive impairment ranges from $11 \%$ to $71 \%$ [32]. The most affected areas in cognition are attention, episodic memory, working memory, executive functions, motor performance, and constructional abilities [27, 28]. A study in the elderly population shows that not only OSA was connected with higher CI, but also noted that after six months of continuous positive airway pressure (CPAP) treatment the cognitive performance improved in some domains [29]. Moreover, after the performance of adenotonsillectomy researchers observed a small and selective but statistically important positive effect on cognitive tests in children [33]. Connection is also found by a large meta-analysis from nineteen studies done in 2016 by Stranks and Crowe [28].

Studies suggest that the OSA severity level has a connection with CI [34, 35, 36]. Yusop et al. in 2017 used Mini-Mental State Examination to determine the cognitive impairment of patients with OSA. The research found that people with a severe level of disorder had significantly worse cognitive performance in comparison to those, who present moderate intensity of OSA. However, none of the patients with moderate levels had any deviation from normal performance [34]. A similar finding was found in 2018 where the severity of disorder correlated with CI, but the difference between the whole OSA group and control was not found [35]. Mini-Mental State Examination could not be a very precise tool to detect mild impairment in those groups of patients. $\mathrm{Mu}$ et al. propose the use of Memory and Executive Screening (MES) for assessing the presence and severity of CI in OSA [36] which could bring more insides into the connection between those disorders.

The cause of CI in OSA patients is still not fully understood. From the 2018 meta-analysis, it can be concluded that hypoxia/hypercarbia caused by short-term sleep disturbance present in OSA has an important role in $\mathrm{CI}$ in attention and memory performance. Nevertheless, the authors suggest also the presence of another mechanism accountable for CI other domains [30]. Castronovo et al. in 2014 noted the presence of the significant improvement of cognitive and functional deficits after CPAP. After the treatment, some structural neural injuries in OSA in patients had reverse those injuries could likely be a reason for $\mathrm{CI}$ [37]. In other research, there is mention of the possible presence of a genetic component in CI is OSA. In experimental models of those diseases, it was showed that they have similar characteristics with Alzheimer's disease, among others, genetic predisposition ApoE4, hippocampus, and synaptic plasticity abnormalities [36].

\section{OSA and anxiety disorder}

The link between anxiety and OSA has been found by several studies [15, 23, 24, 38]. The prevalence of anxiety symptoms in OSA changes depending on studies and was assumed to range from $11 \%$ to $70 \%$ [39] with the mean of $32 \%$ [40], as for present OSA in anxiety disorder it is suggested to be between $6.4 \%$ [19] and $57.1 \%$ [15]. The connection was found to be bidirectional as Kaufmann et al. (2017) estimated that OSA increases 3.68 times probability of anxiety [24] and Ceide et al. (2015) founded that patients with moderate to severe anxiety had a 3.30 higher risk of OSA [38]. A few long-term studies showed that CPAP has a positive effect on both disorders [39]. A meta-analysis from 2016 investigated 31 reports and found a moderately positive effect on anxiety symptoms in OSA patients after positive airway pressure treatment. The effect has only been seen in comparison to placebo and its lack in randomized placebo-controlled trials [41].

The presence of symptoms of OSA also plays a key role in anxiety. In 2018 it was noted that anxiety disorder was found in $18.1 \%$ of symptomatic OSA and only in $2.9 \%$ of asymptomatic. Symptomatic OSA patients were significantly more anxious ( $p<0.0001)$ compared to asymptomatic [35]. In the study from 2012 OSA patients 
who suffer or not from anxiety disorders were compared. At the beginning, the AHI was the same. However, after one year of lifestyle changes, the AHI rose in people with anxiety, and the anxiety level was linearly associated with the severity of mild OSA [42]. The authors conclude that anxiety inhibits positive effects which could be profited from changes in people's lifestyles with OSA [42]. A possible explanation of these connections is pro-inflammatory status, which is involved in the pathophysiology of OSA, as well as in anxiety disorders $[43,44]$. Anxiety was found to intensify low-grade inflammation which could increase OSA symptoms [45]. Anxiety increases sympathetic nerve tone which with inflammatory mediators, can contribute to the pathogenesis of OSA and vice versa [46].

However, there are many controversial findings noted by different research $[39,25]$. In a review made by Saunamaki and Jehkonen, it was noted that in a large number of studies the anxiety is a secondary disorder to OSA [39]. Even some researchers come to the conclusion that there is no association between current anxiety and OSA [25]. As the bidirectional correlation is suggested, the treatment of anxiety disorders as cognitive behavioral therapy should have some effect on OSA symptoms. Unfortunately, there is no such evidence [47]. A systematic review from 2015 noted that there is too insufficient evidence to draw conclusions about the relationship of those disorders. The anxiety disorders represented the most heterogeneous group and studies analyzed the connection with OSA separating each type of disorder or putting them all together [15].

\section{OSA and depressive disorder}

Epidemiological studies show that there is a connection between sleep-related breathing disorders and depression $[24,23,35,48,49,50]$. In $21.5 \%$ of depression cases, the OSA coexists [40]. A cross-sectional telephone survey from 2003 carried out in five countries from west Europe noted that nearly a fifth of patients have both disorders [51]. Chen et al. based on an analysis of 16,908 individuals found that depressive disorders are 2.18 times more likely to develop within a year in participants who suffered from OSA [52]. The lifetime prevalence of major depressive disorder ranges within countries from $3 \%$ to $16.9 \%$ [53]. In OSA patients the prevalence ranges from $22.7 \%$ to $33.9 \%[54,55,56]$. Evidence indicates that continuous positive airway pressure in the treatment of OSA can have a positive impact on depressive symptoms $[41,54,57]$, quality of life, sleep-related symptoms, anxiety, and neurocognition [41, 57]. However, in a randomized placebo-controlled study researchers tested the use of CPAP, and a therapeutic effect on mood symptoms in patients with OSA was not found [58]. The study has a few limitations as a short period of treatment
(3 weeks), which could have affected the results.

Some symptoms are shared by OSA and depression. As they overlap, it could lead to a possible erroneous connection of those two disorders. OSA manifestation could be misdiagnosed for depression, that is why treatment of it elevated the depressive symptoms [41]. OSA consequences and risk factors such as obesity, hypertension, and the decreased quality of life, can be a link of those two [58]. In 2021 Frangopoulos et al. showed that there is a statistically important difference between symptomatic and asymptomatic patients. Those who suffer from symptomatic OSA were more depressed using the Hospital Anxiety and Depression Scale score [59].

Some researchers suggest OSA patients do not only suffer from depressive symptoms caused by OSA but they have mood components as well [60]. A pilot study published in 2020 found that there is no association between OSA and depression severity. They noted that, even though those diseases coexist, they are independent states [61]. In many meta-analyses and systematic reviews, researchers could not draw unequivocal and clear conclusions [15, 40, 62]. Gupta and Simpson (2015) stated in their systematic review that there is limited evidence for elevated risk of OSA in major depressive disorder [15]. An article published online in 2018 showed that pooled prevalence of depressive symptoms in OSA patients is $35.0 \%$. They did not observe the association between OSA severity and the presence of depressive symptoms. Nonetheless, they show that those conditions share a possible bidirectional relationship [40]. In another research from 2020 authors did not find a clear connection between OSA and depression. However, from a meta-analysis of five longitudinal studies, they observed an increased risk of depression over time in patients with OSA in comparison to the general population [62].

\section{OSA and psychotic disorders}

The correlation between OSA and psychotic illnesses including schizophrenia ( $\mathrm{SCH}$ ) is still hard to determine. The prevalence of sleep apnea in a group of patients suffering from psychotic disorders and $\mathrm{SCH}$ is estimated within a wide range of $5.1 \%$ to $57.1 \%[19,63,64]$. Such a large spread of dissemination resulted from the inclusion of studies that differed in many aspects, incl. the inclusion and exclusion criteria (age, level of obesity), the tests used [63]. Sharafkhaneh et al. (2005) performed a large cohort study in which they concluded that OSA is 1.35 times more commonly found in patients with pooled schizophrenia and psychotic disorders [19].

OSA is a common and frequently under-recognized condition in SCH [65]. Alam et al. suggest a need for screening for OSA in psychiatric patients as in his study $62 \%$ of people who suffered from SCH had a high risk 
of OSA and never were considered for sleep-related diagnoses [66]. Older age, higher body mass index (BMI), male gender, smoking, and drinking alcohol were noted to be risk factors for OSA in this population $[64,67]$. Those patients are two times more obese [68], have higher usage of tobacco products, and higher alcohol consumption than healthy people $[69,70]$. OSA symptoms are also overlapping with those illnesses and psychotropic medication induced side effects [66]. Atypical antipsychotic medications were found to have increased risk for OSA due to weight gain [71] but in Rishi et al. investigation the correlation was discovered to be independent to BMI increase [72].

Gupta and Simpson (2015) summarize the results of 10 case reports. They saw in 9 of them an improvement in daytime sleepiness and negative psychotic symptoms in patients using CPAP treatment [15]. However, it cannot draw any clear conclusion from it, due to the lack of welldesigned randomized double-blind clinical trials assessing the influence of OSA treatment on SCH symptoms [15]. The quantitative amounts of antipsychotic use were found to be significantly lowering the AHI level in patients with psychotic disorder [73].

\section{OSA and bipolar disorder}

The scientists also search for a link between bipolar disorder (BD) and OSA. The prevalence of OSA among patients suffering from bipolar disorder is $24.5 \%$ [64] and $15 \%$ of BD in OSA patients [66]. Other authors show a much smaller scale of these phenomena 3.3\% [74] and $4.6 \%$, respectively [75].

In the literature, the bidirectional correlation is well observed. Plante and Winkelman (2008) suggest that impaired sleep, in particular, case of OBS, can induce and predict manic episodes, and OBS in BD patients can be a cause of treatment resistance [76]. Additionally, few cases were noted induction of manic episode after CPAP treatment [77]. However, there are only a few reports of such cases, which could be exceptional. Other researchers also stated that BD treatment with benzodiazepine derivatives and atypical antipsychotics can aggravate OBS symptoms [78]. It can be due to association with side effects (weight gain) of them, which are risk factors for OSA development [79]. There is a lack of well-designed clinical studies to show correlations between bipolar disorder (BD) and OSA.

\section{Discussion}

The purpose of this article review was to summarize the current state of knowledge of the possible correlation between OSA and selective mental disorders. The knowledge gathered so far does not allow for drawing unequivocal conclusions. There are a lot of biases due to different study protocols and inclusion/exclusion criteria.
Nevertheless, it seems that some disorders have a better proven correlation with OSA. Cognitive impairment, depression, and anxiety disorders are linked to OSA not only in terms of the overlapping of symptoms but also of a causal relationship [23, 24, 27, 29, 48, 49]. Psychotic disorders and bipolar disorders connections with sleep apnea are confirmed, but it is not yet well understood [15, 63]. All correlations are found to be possibly bidirectional $[19,24,26,38,40,47]$

Psychiatric disorders and OSA have a negative effect on the central nervous system [80]. Increased activity of the sympathetic nervous system is found by OSA which can increase anxiety symptoms [5]. Furthermore, the mental disorders lead to hyperactivity and hyperarousal states and resultant sleep fragmentation may cause upper airway instability, which may contribute to subsequent OSA [80]. As they progress, the severity of dysfunction of the nervous and endocrine system increases [15]. In many studies, this correlation is noted. As the symptoms of one disease elevate, it explains the higher-level outcome of the second disorder [34, 35, 36, 40, 42]. Except in schizophrenia, where only the usage of the neuroleptic drugs correlated with the OSA [73].

Intermittent hypoxia during sleep characteristic for obstructive sleep apnea has been found to damage the brain matter (especially the hippocampus) by oxidative stress mechanism via the systemic circulation [81]. This observation could explain why OSA can cause impairment in cognition and memory. Canessa et al. (2010) examined the effect of CPAP treatment on the volume of the gray matter of OSA patients. The authors confirmed a reduction of brain matter in untreated OSA patients. Significant improvement of gray-matter volume in the left hippocampus, left posterior parietal cortex, and right superior frontal gyrus was observed after the treatment [82]. The same pattern was observed in white matter integrity in OSA patients. The damage can be partially reversed with treatment of OSA resulting in improvement of cognition functions [37].

Considering the mechanism of action which would explain the observed phenomenon of the frequent occurrence of OSA in the course of mental disorders, it should be emphasized the important role in psychiatric disorders oxidative and nitrosative stress, inflammation, and neurotransmitter imbalances [83]. It alters the neurobiological and endocrine function which contributes to cardiovascular diseases, obesity, and diabetes [15, 83]. As those outcomes are frequent in psychiatric patients, it connects to OSA as they are all independent predictors of it $[15,24,28,64,67]$.

\section{Limitations}

Despite the fact that during the preparation of this 
manuscript the authors put effort to review the current research on the connection between OSA and psychiatric disorders in the best way, it has some limitations of this paper should be addressed. Firstly, it is a narrative, not a systematic review, so not all researches could be included in this work. Secondly, we looked through original studies, meta-analyses, and review articles, and drew a conclusion on their results. The overall quality of the evidence can be questionable. Thirdly, we only looked at studies in the English language that may have limited our final results. Due to some limitations, the results of this review need to be interpreted with caution.

\section{Conclusion}

1. Multiple lines of evidence increasingly point towards a bidirectional connection between obstructive sleep apnea and mental disorders, and the cause and effect relationship between these two groups of disorders require further research [23, 24, 26, 27, 29, 48, 49].

2. There is a high prevalence of OSA in mental disorders ranges: anxiety disorder from $6.4 \%$ [19] to $57.1 \%$ [15], depressive disorder around $21.5 \%$ [40], psychotic disorders from $5.1 \%$ to $57.1 \%$ [19, $63,64]$, bipolar disorder from $4.6 \%$ [75] to $15 \%$ [66], cognitive impairment from $11 \%$ to $71 \%$ [32].

3. The prevalence of mental disorders in OSA is estimated in wide ranges: anxiety disorder from $11 \%$ to $70 \%$ [39], depressive disorder from $22.7 \%$ to $33.9 \%[54,55,56]$, bipolar disorder from $3.3 \%$ [74] to $24.5 \%$ [64], cognitive impairment is $47.9 \%$ [31].

4. Due to reports of an increased risk of OSA with antipsychotic drugs, caution should be exercised when initiating therapy with this type of drug in patients with known risk factors for OSA [71, 72, 78].

5. Screening for OSA in psychiatric patients should be introduced as OSA can increase cognitive impairment [31, 34, 35, 36], affective [24], and depressive symptoms [24].

6. There is a need for further research on the relationship between mental disorders and obstructive sleep apnea, especially well-designed randomized clinical trials.

\section{Conflict of interest}

The authors has declared no conflict of interest.

\section{References}

1. White D.P. Sleep-related breathing disorder: 2pathophysiology of obstructive sleep apnoea. Thorax, 1995; 50: 797-804.
2. Qamar A., Qureshi M., Nazar S., Baig S., Iffat W., Owais M. Physical activity and apnoea-hypopnea index in obstructive sleep apnoea. PJP [Internet]. [cited 17 Aug. 2021]; 15(3):67-0. Available from: http://www.pjp.pps.org.pk/index.php/PJP/ article/view/1116

3. Healthysleep.med.harvard.edu [home page on the Internet]. Understanding the Results; 2011 [updated Feb 11, 2011; cited Sep 7, 2021]. Accessible at: https://healthysleep.med.harvard. edu/sleep-apnea/diagnosing-osa/understanding-results

4. Rundo J.V. Obstructive sleep apnea basics. Cleve Clin J Med. 2019;86:2-9.

5. Heinzer R., Vat S., Marques-Vidal P., Marti-Soler H., Andries D., Tobback N., et al. Prevalence of sleep-disordered breathing in the general population: the HypnoLaus study. Lancet Respir Med. 2015;3(4):310-8.

6. Al Lawati N.M., Patel S.R., Ayas N.T. Epidemiology, risk factors, and consequences of obstructive sleep apnea and short sleep duration. Prog Cardiovasc Dis. 2009;51(4):285-93.

7. Franklin K.A., Lindberg E. Obstructive sleep apnea is a common disorder in the population-a review on the epidemiology of sleep apnea. J Thorac Dis. 2015;7(8):1311-22.

8. Tufik S., Santos-Silva R., Taddei J.A., Bittencourt L.R. Obstructive sleep apnea syndrome in the Sao Paulo Epidemiologic Sleep Study. Sleep Med. 2010;11(5):441-6.

9. Young T., Peppard P.E., Gottlieb D.J.. Epidemiology of obstructive sleep apnea: a population health perspective. Am. J. Respir. Crit. Care Med. 2002; 165: 1217-1239.

10. Reuveni H., Tarasiuk A., Wainstock T., Ziv A., Elhayany A., Tal A. Awareness level of obstructive sleep apnea syndrome during routine unstructured interviews of a standardized patient by primary care physicians. Sleep 2004;27:1518-1525.

11. Kapur V., Strohl K.P., Redline S., Iber C., O'Connor G., Nieto J. Underdiagnosis of sleep apnea syndrome in U.S. communities. Sleep Breath. 2002; 6: 49-54

12. Punjabi N.M., Polotsky V.Y. Disorders of glucose metabolism in sleep apnea. J Appl Physiol (1985) 2005; 99: 1998-2007

13. Knauert M., Naik S., Gillespie M.B., Kryger M. Clinical consequences and economic costs of untreated obstructive sleep apnea syndrome. World J Otorhinolaryngol Head Neck Surg. 2015;1(1):17-27.

14. Faber J., Faber C., Faber A.P. Obstructive sleep apnea in adults. Dental Press J Orthod. 2019;24(3):99-109.

15. Gupta M.A., Simpson F.C. Obstructive sleep apnea and psychiatric disorders: a systematic review. J Clin Sleep Med. 2015;11(2):165-175.

16. Harris M., Glozier N., Ratnavadivel R., Grunstein R.R. Obstructive sleep apnea and depression. Sleep Med Rev. 2009;13(6):437-44.

17. Grigg-Damberger M., Ralls F. Cognitive dysfunction and obstructive sleep apnea: from cradle to tomb. Curr Opin Pulm Med. 2012;18(6):580-7.

18. Vanek J., Prasko J., Genzor S., Ociskova M., Kantor K., Holubova M., et al. Obstructive sleep apnea, depression and cognitive impairment. Sleep Med. 2020;72:50-58.

19. Sharafkhaneh A., Giray N., Richardson P., Young T., Hirshkowitz M. Association of psychiatric disorders and sleep apnea in a large cohort. Sleep. 2005;28(11):1405-11..

20. Mellman T.A. In Psychiatric Clinics of North America. Sleep Med Clin. 2008;3(2):261-268.

21. Lee M.H., Lee S.A., Lee G.H., Ryu H.S., Chung S., Chung Y.S., et al. Gender differences in the effect of comorbid insomnia symptom on depression, anxiety, fatigue, and daytime sleepiness in patients with obstructive sleep apnea. Sleep Breath. 2014;18(1):111-7.

22. Karkoulias K., Lykouras D., Sampsonas F., Karaivazoglou K., 
Sargianou M, Drakatos P, et al. The impact of obstructive sleep apnea syndrome severity on physical performance and mental health. The use of SF-36 questionnaire in sleep apnea. Eur Rev Med Pharmacol Sci. 2013;17(4):531-6.

23. Rezaeitalab F., Moharrari F., Saberi S., Asadpour H., Rezaeetalab F. The correlation of anxiety and depression with obstructive sleep apnea syndrome. J Res Med Sci. 2014;19(3):205-10.

24. Kaufmann C.N., Susukida R., Depp C.A. Sleep apnea, psychopathology, and mental health care. Sleep Health. 2017;3(4):244-249.

25. Guilleminault C., Tilkian A., Dement W.C. The sleep apnea syndromes. Annu Rev Med. 1976;27:465-84.

26. Knechtle B., Economou N.-T., Nikolaidis P.T., Velentza L., Kallianos A., Steiropoulos P., et al. Clinical Characteristics of Obstructive Sleep Apnea in Psychiatric Disease. Journal of Clinical Medicine. 2019; 8(4):534.

27. Ferini-Strambi L., Baietto C., Di Gioia M.R., Castaldi P., Castronovo C., Zucconi M, et al. Cognitive dysfunction in patients with obstructive sleep apnea (OSA): partial reversibility after continuous positive airway pressure (CPAP). Brain Res Bull 2003;61:87-92.

28. Stranks E.K., Crowe S.F. The Cognitive Effects of Obstructive Sleep Apnea: An Updated Meta-analysis. Arch Clin Neuropsychol. 2016;31(2):186-93.

29. Gutiérrez Iglesias B., Jacas Escarceller C., Bardés Robles I., Cambrodi Masip R., Romero Santo-Tomás O., Pujadas Navinés F., et al. Effectiveness of 6-months continuous positive airway pressure treactment in OSAS-related cognitive deficit in older adults. Behav Neurol. 2013;26(3):191-4.

30. Olaithe M., Bucks R.S., Hillman D.R., Eastwood P.R. Cognitive deficits in obstructive sleep apnea: Insights from a meta-review and comparison with deficits observed in COPD, insomnia, and sleep deprivation. Sleep Med Rev. 2018;38:39-49.

31. Beaudin A.E., Raneri J.K., Ayas N.T., Skomro R.P., Fox N., Hirsch Allen A.J.M., et al. Cognitive Function in a Sleep Clinic Cohort of Patients with Obstructive Sleep Apnea. Ann Am Thorac Soc. 2021;18(5):865-875.

32. Mubashir T., Abrahamyan L., Niazi A., Piyasena D., Arif A.A., Wong J., et al. The prevalence of obstructive sleep apnea in mild cognitive impairment: a systematic review. BMC Neurol. 2019;19(1):195.

33. Taylor H.G., Bowen S.R., Beebe D.W., Hodges E., Amin R., Arens R., et al. Cognitive Effects of Adenotonsillectomy for Obstructive Sleep Apnea. Pediatrics. 2016;138(2):e20154458.

34. Yusop C.Y.C., Mohamad I., Mohammad W.M.Z.W., Abdullah B. Cognitive Function Among Obstructive Sleep Apnea Patients in North East Malaysia. J Natl Med Assoc. 2017;109(3):215-220.

35. Bilyukov R.G., Nikolov M.S., Pencheva V.P., Petrova D.S., Georgiev O.B., Mondeshki T.L., et al. Cognitive Impairment and Affective Disorders in Patients with Obstructive Sleep Apnea Syndrome. Front Psychiatry. 2018;9:357.

36. Mu L., Peng L., Zhang Z., Jie J., Jia S., Yuan H. Memory and Executive Screening for the Detection of Cognitive Impairment in Obstructive Sleep Apnea. Am J Med Sci. 2017;354(4):399-407.

37. Castronovo V., Scifo P., Castellano A., Aloia M.S., Iadanza A., Marelli S., et al. White matter integrity in obstructive sleep apnea before and after treatment. Sleep. 2014;37(9):1465-75.

38. Ceïde M.E., Williams N.J., Seixas A., Longman-Mills S.K., JeanLouis G. Obstructive sleep apnea risk and psychological health among non-Hispanic blacks in the Metabolic Syndrome Outcome (MetSO) cohort study. Ann Med. 2015;47(8):687-93.

39. Saunamäki T., Jehkonen M. Depression and anxiety in obstructive sleep apnea syndrome: a review. Acta Neurol Scand. 2007;116(5):277-88.
40. Garbarino S., Bardwell W.A, Guglielmi O., Chiorri C., Bonanni E., Magnavita N. Association of Anxiety and Depression in Obstructive Sleep Apnea Patients: A Systematic Review and Meta-Analysis. Behav Sleep Med. 2020;18(1):35-57.

41. Gupta M.A., Simpson F.C., Lyons D.C. The effect of treating obstructive sleep apnea with positive airway pressure on depression and other subjective symptoms: A systematic review and meta-analysis. Sleep Med Rev. 2016; 28:55-68.

42. Lehto S.M., Sahlman J., Soini E.J., Gylling H., Vanninen E., Seppä J., et al. The association between anxiety and the degree of illness in mild obstructive sleep apnoea. Clin Respir J. 2013;7(2):197203.

43. O'Donovan A., Hughes B.M., Slavich G.M., Lynch L., Cronin M.T., O'Farrelly C., et al. Clinical anxiety, cortisol and interleukin-6: evidence for specificity in emotion-biology relationships. Brain Behav Immun. 2010;24: 1074-7.

44. Sahlman J., Miettinen K., Peuhkurinen K., Seppä J., Peltonen M., Herder C., et al. The activation of the inflammatory cytokines in overweight patients with mild obstructive sleep apnoea. J Sleep Res. 2010;19(2):341-8.

45. Narita K., Murata T., Hamada T., Takahashi T., Omori M., Suganuma N., et al. Interactions among higher trait anxiety, sympathetic activity, and endothelial function in the elderly. J Psychiatr Res. 2007;41: 418-27

46. Diaz S.V., Brown L.K. Relationships between obstructive sleep apnea and anxiety. Curr Opin Pulm Med. 2016;22(6):563-9.

47. Sweetman A., Lack L., McEvoy R.D., Catcheside P.G., Antic N.A., Chai-Coetzer C.L., et al. Effect of depression, anxiety, and stress symptoms on response to cognitive behavioral therapy for insomnia in patients with comorbid insomnia and sleep apnea: a randomized controlled trial. J Clin Sleep Med. 202;17(3):545554.

48. Peppard P.E., Szklo-Coxe M., Hla K.M., Young T. Longitudinal association of Sleep-Related Breathing Disorder and Depression. Arch Intern Med. 2006;166(16):1709-1715.

49. Wheaton A.G., Perry G.S., Chapman D.P., Croft J.B. Sleep disordered breathing and depression among U.S. adults: National Health and Nutrition Examination Survey, 2005-2008. Sleep. 2012;35(4):461-7.

50. BaHammam A.S., Kendzerska T., Gupta R., Ramasubramanian C., Neubauer D.N., Narasimhan M., et al. Comorbid depression in obstructive sleep apnea: an under-recognized association. Sleep Breath. 2016;20(2):447-56.

51. Ohayon M.M. The effects of breathing-related sleep disorders on mood disturbances in the general population. J Clin Psychiatry. 2003;64(10):1195-200.

52. Chen Y.H., Keller J.K., Kang J.H., Hsieh H.J., Lin H.C. Obstructive sleep apnea and the subsequent risk of depressive disorder: a population-based follow-up study. J Clin Sleep Med. 2013;9(5):417-23.

53. Andrade L., Caraveo-Anduaga J.J., Berglund P., Bijl R.V., De Graaf R., Vollebergh W., et al. The epidemiology of major depressive episodes: results from the International Consortium of Psychiatric Epidemiology (ICPE) Surveys. Int J Methods Psychiatr Res. 2003;12(1):3-21.

54. El-Sherbini A.M., Bediwy A.S., El-Mitwalli A. Association between obstructive sleep apnea (OSA) and depression and the effect of continuous positive airway pressure (CPAP) treatment. Neuropsychiatr Dis Treat. 2011;7:715-21.

55. Jackson M.L., Tolson J., Bartlett D., Berlowitz D.J., Varma P., Barnes M. Clinical depression in untreated obstructive sleep apnea: examining predictors and a meta-analysis of prevalence rates. Sleep Med. 2019; 62: 22-28.

56. Eldahdouh S.S., El-Habashy M.M., Elbahy M.S. Effect of CPAP 
on depressive symptoms in OSA. Egypt J Chest Dis Tuberc. 2014;63(2):389e93.

57. Martínez-García M.Á., Chiner E., Hernández L., Cortes J.P., Catalán P., Ponce S., et al.; Spanish Sleep Network. Obstructive sleep apnoea in the elderly: role of continuous positive airway pressure treatment. Eur Respir J. 2015;46(1):142-51.

58. Lee I.S., Bardwell W., Ancoli-Israel S., Loredo J.S., Dimsdale J.E. Effect of three weeks of continuous positive airway pressure treatment on mood in patients with obstructive sleep apnoea: a randomized placebo-controlled study. Sleep Med. 2012;13(2):161-6.

59. Hobzova M., Prasko J., Vanek J., Ociskova M., Genzor S., Holubova M., et al. Depression and obstructive sleep apnea. Neuro endocrinology letters. 2017; 38. 343-352.

60. Frangopoulos F., Zannetos S., Nicolaou I., Economou N.T., Adamide T., Georgiou A., et al. The Complex Interaction Between the Major Sleep Symptoms, the Severity of Obstructive Sleep Apnea, and Sleep Quality. Front Psychiatry. 2021;12:630162.

61. Means M.K., Lichstein K.L., Edinger J.D., Taylor D.J., Durrence H.H., Husain A.M., et al. Changes in depressive symptoms after continuous positive airway pressure treatment for obstructive sleep apnea. Sleep Breath. 2003;7(1):31-42.

62. van Wyk M., McCreesh-Toselli S., Williams S., O Ebrahim I. The distinct roles of OSA and depression severity in day- and nighttime symptomatology in OSA patients: a pilot study. Sleep Breath. 2020;24(3):931-939.

63. Edwards C., Almeida O.P., Ford A.H. Obstructive sleep apnea and depression: A systematic review and meta-analysis. Maturitas. 2020;142:45-54.

64. Myles H., Myles N., Antic N.A., Adams R., Chandratilleke M., Liu D., et al. Obstructive sleep apnea and schizophrenia: A systematic review to inform clinical practice. Schizophr Res. 2016;170(1):222-5.

65. Stubbs B., Vancampfort D., Veronese N., Solmi M., Gaughran F., Manu P., et al. The prevalence and predictors of obstructive sleep apnea in major depressive disorder, bipolar disorder and schizophrenia: A systematic review and meta-analysis. J Affect Disord. 2016;197:259-67.

66. Kalucy M.J., Grunstein R., Lambert T., Glozier N. Obstructive sleep apnoea and schizophrenia--a research agenda. Sleep Med Rev. 2013;17(5):357-65.

67. Alam A., Chengappa K.N., Ghinassi F. Screening for obstructive sleep apnea among individuals with severe mental illness at a primary care clinic. Gen Hosp Psychiatry. 2012;34(6):660-4.

68. Kaskie R.E., Graziano B., Ferrarelli F. Schizophrenia and sleep disorders: links, risks, and management challenges. Nat Sci Sleep. 2017;9:227-239.

69. Boufidis S., Kosmidis M.H., Bozikas V.P., SkalopoulouVlahoyianni E., Pitsavas S., Karavatos A. Treatment outcome of obstructive sleep apnea syndrome in a patient with schizophrenia: case report. Int. J. Psychiatry Med. 2003; 33: 305-310.

70. Szaulińska K., Pływaczewski R., Sikorska O., Holka-Pokorska J., Wierzbicka A., Wichniak A., et al. Obstructive sleep apnea in severe mental disorders. Psychiatr Pol. 2015;49(5):883-95.

71. Seeman M.V. Diagnosis and treatment of sleep apnoea in women with schizophrenia. J Ment Health. 2014;23(4):191-6.

72. Darwish M., Bond M., Yang R., Hellriegel E.T., Robertson P. Evaluation of potential pharmacokinetic drug-drug interaction between armodafinil and risperidone in healthy adults. Clin Drug Investig. 2015;35(11):725-33.

73. Rishi M.A., Shetty M., Wolff A., Amoateng-Adjepong Y., Manthous C.A. Atypical antipsychotic medications are independently associated with severe obstructive sleep apnea. Clin
Neuropharmacol. 2010;33(3):109-13.

74. Anderson K.N., Waton T., Armstrong D., Watkinson H.M., Mackin P. Sleep disordered breathing in community psychiatric patients. Eur. J. Psychiat. 2012; 26( 2 ): 86-95.

75. Joo E.Y., Tae W.S., Lee M.J., Kang J.W., Park H.S., Lee J.Y., et al. Reduced brain gray matter concentration in patients with obstructive sleep apnea syndrome. Sleep. 2010;33(2):235-41.

76. Schröder C.M., O'Hara R. Depression and Obstructive Sleep Apnea (OSA). Ann Gen Psychiatry. 2005;4:13.

77. Plante D.T., Winkelman J.W. Sleep disturbance in bipolar disorder: therapeutic implications. Am J Psychiatry. 2008;165:830-43.

78. Aggarwal R., Baweja R., Saunders E.F., Singareddy R. CPAPinduced mania in bipolar disorder: a case report. Bipolar Disord. 2013;15(7):803-807.

79. Thompson W.K., Kupfer D.J., Fagiolini A., Scott J.A., Frank E. Prevalence and clinical correlates of medical comorbidities in patients with bipolar I disorder: analysis of acute-phase data from a randomized controlled trial. J Clin Psychiatry. 2006;67(5):783-8.

80. Chengappa K.N., Suppes T., Berk M. Treatment of bipolar mania with atypical antipsychotics. Expert Rev Neurother. 2004;4:17S25.

81. Sériès F., Roy N., Marc I. Effects of sleep deprivation and sleep fragmentation on upper airway collapsibility in normal subjects. Am J Respir Crit Care Med. 1994;150(2):481-5.

82. Gozal D., Row B.W., Gozal E., Kheirandish L., Neville J.J., Brittian K.R., et al. Temporal aspects of spatial task performance during intermittent hypoxia in the rat: evidence for neurogenesis. Eur J Neurosci. 2003;18(8):2335-42.

83. 82. Canessa N., Castronovo V., Cappa S.F., Aloia M.S., Marelli S., Falini A., et al. Obstructive sleep apnea: brain structural changes and neurocognitive function before and after treatment. Am J Respir Crit Care Med. 2011;183(10):1419-26.

84. Lopresti A.L., Drummond P.D. Obesity and psychiatric disorders: commonalities in dysregulated biological pathways and their implications for treatment. Prog Neuropsychopharmacol Biol Psychiatry. 2013;45:92-9.

\section{Corresponding author}

Aleksander Ryczkowski

Department of Family Medicine,

Medical University of Lublin,

Langiewicza Street 6A, 20-035 Lublin, Poland

aleksanderryczkowski@gmail.com

Otrzymano: 08.09.2021

Zrecenzowano: 09.09.2021

Przyjęto do druku: 17.09.2021 